\title{
Do markets promote more efficient and higher value water use? Tracing evidence over time in an Australian water market
}

\author{
H. Bjornlund ${ }^{1,2}$ \\ ${ }^{1}$ University of South Australia, Australia \\ ${ }^{2}$ University of Lethbridge, Canada
}

\begin{abstract}
This paper analyses buyers and sellers of water entitlements in Australia based on surveys conducted during three time periods from 1992 to 2006 to identify whether water markets have facilitated a reallocation of water from inefficient, unproductive and low-value users to efficient, productive and high-value users. There is evidence that the entitlement market has an increasing impact on the way water is used and facilitates reallocation. While the early markets mainly activated previously unused water, there is evidence that as the market matures, more actively used water is being sold reducing the productive capacity of the selling property. The evidence suggests that many sellers reduced their irrigated area during the last five years, in response to prices in the seasonal market for water allocations, before eventually selling their entitlement.
\end{abstract}

Keywords: water trading, water reallocation, community impact, Australia.

\section{Introduction}

As water scarcity intensifies around the world water markets are increasingly being proposed to facilitate a reallocation of water from inefficient low-value users to efficient high-value users to minimize the overall economic impact of scarcity. The expectation is that the buyers will be able and willing to pay the sellers a price that compensates them for their losses. However markets in water entitlements (the market in which the long term entitlement to receive annual water allocations is traded) have been slow to evolve. Australia is one of a few countries where entitlement markets have been operating for some time. Australia therefore provides an opportunity to investigate whether the market has 
achieved the anticipated outcomes. This paper investigates this using the Goulburn-Murray Irrigation District (GMID) in Victoria as a case study. The author has previously analysed the impacts of water trading during the first five years of trading [1-5] and the results indicate that the anticipated reallocation takes place. It was, however, pointed out that the outcome of these early markets should be seen as indicative only, as activities in the market were limited, with less than $0.5 \%$ of the entitlement base traded each year, and the early markets were dominated by unused water with about $50 \%$ of the water sold not being used by the sellers. Ten years later these conditions have changed. Market participation has increased [6] and the volume traded has during the last three years been about $2.5 \%$ p.a. of the entitlement base [7] and the volume of unused water is likely to have declined. This paper analyses water trading for the three year period 2003-2006 based on surveys of buyers and sellers to identify the extent to which the anticipated reallocation takes place. These findings are then compared with the previous findings from the period 1992-1996. The paper first provides a brief overview of the emergence of water markets in Australia and within the case study area and how trading activities have developed.

\section{The introduction of water trading in Australia - an overview}

Water trading was first introduced in the south-eastern part of Australia where water resources within the Murray-Darling Basin (MDB) showed the first signs of over allocation with the result that over time a moratorium was placed on the issuing of new water entitlements within most catchments. When demand for water increased from new or expanding water users it could only be met by reallocating existing entitlements. At the same time there was an interest in reallocating water away from areas unsuitable for irrigation and away from inefficient and low-value users.

Due to a general concern in the community about the potential impact of the sale of water entitlements, the entitlement market was slow in emerging. During the late 1970s and early 1980s many water authorities allowed informal transfers between farmers to accommodate the need to reallocate water during periods of severe drought. Formal provisions for seasonal trade in water allocations were first made in South Australia (SA) and New South Wales (NSW) in 1984 and pilot programs in some districts were introduced in Victoria in 1987. Markets for water entitlements first emerged in SA in 1984. This state first felt the pressure for mechanisms to permanently reallocate water to meet new demand from horticulture and viticulture since: i) SA had already in the 1970 s reduced irrigators' entitlements according to actual use; ii) horticulture and viticulture had no interest in trading in water allocations as they need long-term supply security for their high-value and capital intensive permanent crops. Trading in water entitlements were introduced by legislation in NSW in 1989 but did not emerge within the irrigation districts until these were privatized in the mid 1990s. In Victoria trading in allocations and entitlements were introduced by 
legislation in 1989 but entitlement trading did not commence until the necessary regulations were introduced in September 1991.

Two policy initiatives have promoted the adoption of water markets. First, in the early 1990s it became apparent that the MDB had serious water quality problems. This resulted in an audit of water use which found that the Basin was overcommitted for extractive use and that the level of extraction would continue to increase by at least $14 \%$ if no action was taken. Such development would result in further detrimental environmental impacts and threaten the future economic use of water. A Cap was therefore placed on water use within each state set at the 1993/94 level of development. As trade activated unused water, and as drought and increased need for environmental water reduced the consumptive pool, less and less water was allocated each season in order to stay within the Cap. This caused a further increase in water market activities, especially in the markets for seasonal allocations, as irrigators with permanent crops were struggling to secure adequate water.

Second, in 1994 the Council of Australian Governments (CoAG) agreed on a new water policy framework calling for the separation of water entitlements from land, more clearly specified entitlements and water trading [8]. Trade in water entitlements was encouraged to ensure that water is used to maximize its contribution to national income and welfare within social, physical and ecological constraints of catchments. This framework was further strengthened in 2004 with the National Water Initiative (NWI) [9] which emphasises that existing water markets and mechanisms are preventing markets from reaching their full potential and that more efficient market mechanisms and more sophisticated market instruments are necessary. The NWI therefore includes a commitment to: i) introduce water entitlements with nationally compatible characteristics defined as a perpetual share of the available pool of water for consumptive use; ii) introduce secure entitlement registers, where third party interests can be registered; and iii) gradually remove all barriers to trade. It has to be noted that the removal of barriers to trade is associated with substantial opposition within irrigation communities [10].

\section{The introduction of entitlement trading in Victoria}

The first transfers in Victoria were registered in January 1992. To alleviate the concern over the impact of trading in water entitlements, the regulations limited the ability to trade in water in six main ways: i) geographical restrictions on how water could move around; ii) to ease the concern over the impact of trading out of irrigation districts, an annual maximum was set at $2 \%$ of the entitlement base at the beginning of the year; iii) trading was not allowed between different classes of water entitlements such as private irrigators pumping their own water from the rivers and irrigators within the irrigation districts; iv) to ease environmental concerns, limits were placed on how much water could be purchased onto each parcel of land depending on the quality of drainage, laser grading and irrigation technique and trading into certain high impact zones were prohibited; v) to ease the concerns of banks, trade was only allowed following 
consent from third parties with an interest in the land to which the water was attached; and vi) to alleviate concern over channel capacity, trade would only be allowed if the water could be delivered by the existing supply infrastructure without reducing existing water users' supply reliability.

These restrictions have been continually revised: i) in 1994, trading between the two major entitlement types was allowed and trade to outside the GMID was introduced. It was initially feared that his would cause a significant export of water as downstream demand from horticulture and viticulture would drive water in that direction; ii) in 1995, some of the geographical restrictions on trade within the GMID were eased; iii) in 1997 further allowances were made for interstate trading with NSW; iv) under the NWI interstate trading with both NSW and SA was finally agreed in 2006 and the barriers to trade out of districts were expanded from $2 \%$ to $4 \%$ in 2005; and v) in 1995 the regulations as to how much water could be purchased onto a given parcel of land were revised to require that the land on which the water would be applied must be suitable for irrigation. Further revision took place in 1996 when new Salinity and Drainage Guidelines were approved. The major changes were that: i) the limits on how much water could be traded onto a parcel of land were removed and replaced by a limit on how much water could be used. This allowed irrigators to buy more water entitlements to secure against low seasonal allocations; and ii) the need to have suitable land was replaced with the requirement of an irrigation and drainage system consistent with modern practices and suitable for the soil condition and crop type of the farm.

The Victorian government has been reluctant to detach the water entitlement from land ownership. The transfer of water entitlements required that the water authority detach the entitlement from one parcel of land and then attach it to another. The latest policy reform in Victoria (DSE [11]), in compliance with the NWI, finally introduced the separation of land and water rights. To alleviate the community concern that this separation will result in a consolidation of water entitlements into large speculative corporations to the detriment of family farming [10], a rule was introduced that only $10 \%$ of any water resource can be owned by the same entity. It was also decided to introduce a new water use right which will require all water users to prove that they are using the water according to best irrigation and drainage practices. To alleviate the concern that trade out of supply systems would leave the remaining water users with a higher maintenance burden, a separate supply capacity entitlement tied to land was introduced. Charges to cover the cost of infrastructure maintenance will be attached to this capacity entitlement which will remain with the land even after the water entitlement has been sold.

\section{The development of trade within the GMID}

Trading in water entitlements evolved slowly due to a number of factors: i) restrictions on trading discussed in the preceding section; ii) cumbersome administrative procedures; iii) uncertainty associated with the successful completion of transfers; iv) uncertainty about the level of long term allocations 
yielded by the entitlement; and v) perception of water as an inherent part of the farm [12].

During 2005/06 the total volume of water entitlements within the GMID was 1,793,637 ML. Since the first trade of water entitlement to outside the district took place in 1996/97, some 124,265 ML have been exported out of the area, representing a reduction of $6.5 \%$ of the entitlement base. The GMID consists of a number of irrigation districts with very different soil and production characteristics. Export of water out of individual districts has therefore varied substantially. The two districts experiencing the biggest proportional export of water have seen a drop in their entitlement base of some $11.5 \%$ [7].

During the first 15 year of entitlement trading (from 1992 to 2006) 308,666 ML, representing 17.2\% the entitlement base, have changed hands. Even though entitlement trading has been taken up slowly, there are, by the end of the first 14 years, indications that it is starting to have some impact on the distribution of water entitlements. Annual volumes traded have increased from less than $0.5 \%$ of the entitlement base during the first five years to more than $2.5 \%$ during the last three years [7]. Similarly the participation rate of farm businesses started out with only $0.5 \%$ of them active in the market each year increasing to $2.5 \%$ selling and $2 \%$ buying during $2003 / 04$, at which time some $8 \%$ of farm businesses had sold and $8 \%$ had bought water entitlements [6].

\section{Data and methodology}

This paper is based on surveys conducted during three time periods: i) mail questionnaires from 1992-1994 with 337 usable responses representing 58.5\% of all traders; ii) telephone interviews from 1995-1996 of 100 buyers and 100 sellers representing about $30 \%$ of all traders; and iii) mail questionnaires from 2003-06 with 157 useful responses representing some $15 \%$ of all traders. In all instances the sellers' response rate was lower than the buyers' as many sellers are disenfranchised with the industry and therefore will not return the questionnaire. Also, about $7 \%$ of all surveys send to sellers were returned with the person unknown at the address reflecting that these sellers have sold or abandoned their property and have moved in search of a job. The study thus covers the first five years of trading and a three year period after 10 years of market experience. The data was not collected for the purpose of this longitudinal study. Each survey instrument was designed based on the experiences with the preceding instrument and to accommodate the need for more and different data. Consequently, in some instances different questions were asked and longitudinal comparisons were not possible.

\section{Has entitlement trading resulted in more efficient, higher value and more productive water use?}

To determine whether more efficient water use has resulted from entitlement trading, respondents were asked: i) whether they have the various types of irrigation and drainage infrastructure and to which extend their irrigated land is 
serviced by such infrastructure; ii) what they have done over the last five years and what they intend to do over the next five years to improve their irrigation and drainage infrastructure; iii) whether they have a whole of farm plan for their property and use some kind of technical aid to schedule their irrigation; and iv) questions related to their use of extension services, participation in training events, and membership of professional and community organization. To determine whether water has move to more valuable and productive uses, respondents were asked: i) what they produce on their land; ii) what they have done in the last five years and intend to do in the next five years to change production and buy and sell land or water; iii) the size of their irrigated area and water entitlement; iv) whether they find their property to be long-term viable; and v) how they perceive that their productivity is developing. To aid the answer to both questions a number of demographic questions were asked such as: i) age; ii) family background in farming; iii) expectation of family continuity; iv) schooling; v) further education and vi) dependence on off-farm work.

\subsection{Entitlement trading and more efficient water use}

During the early period, there are very clear signs that far more buyers have the various irrigation and drainage infrastructure and also have a larger proportion of their irrigated area serviced by such infrastructure (table 1). This is particularly evident when it comes to re-use systems. This is caused by the dominance of the dairy industry as buyers in the early markets (table 2). During 2003-2006 these trends changed as the difference between the proportion of the buyers and sellers having the various irrigation and drainage infrastructure became less pronounced. This is likely to be caused by at least three factors: i) the irrigation industry has generally gone through a period of infrastructure upgrading both on and off-farm; ii) the changing fortune of the dairy industry. Due to drought, declining allocations, deregulation of the industry, and low commodity prices, the dairy industry has been suffering over the last five to ten years. Therefore far more dairy farms are selling their water and getting out of dairying; and iii) new irrigation methods such as centre pivots, sprinklers and drip irrigation has been introduced ( $20 \%$ of buyers reported other irrigation method than gravity) following the emergence of new and higher value industries such as viticulture, olives and vegetables (tomatoes) (13.2\% of buyers, table 2$)$. These productions do not benefit from laser grading, re-use system and off-farm drainage as this infrastructure is mainly used a measures to improve the efficiency of gravity irrigation. There is also a significantly larger percentage of buyers having a whole of farm plan and using aid in scheduling their irrigation, indicating more efficient water use.

During the early period it can also be seen (table 1) that many of the buyers of entitlements installed this irrigation and drainage infrastructure subsequent to the purchase of the water, making the difference between buyers and sellers even more pronounced. This trend is also evident during the second period, with a significantly larger percentage of buyers having improved their irrigation and drainage infrastructure the last five years and expecting to do so the next five years. From table 3 it is also apparent that the buyers are younger with more 
agricultural qualifications and more actively participating in training events and using extension services suggesting that this group are more likely to be actively pursuing more efficient water use and the introduction of more efficient irrigation technology. Finally if we consider that more viable farms with continuity of family ownership are likely to result in more efficient water use, then table 3 clearly shows that the buyers consider their property to be more viable with an increasing production. This is supported by the fact that the buying properties are considerable larger and have considerable larger water entitlements, especially during the last period (table 2).

Table 1: $\quad$ Water use practices and past and future farm changes.

\begin{tabular}{|c|c|c|c|c|c|c|c|c|}
\hline & \multicolumn{4}{|l|}{ 1994-96 } & \multicolumn{4}{|l|}{$2003-06$} \\
\hline & \multicolumn{2}{|c|}{$\%$ of water } & \multicolumn{2}{|c|}{$\%$ of area } & \multicolumn{2}{|c|}{$\%$ of respondents } & \multicolumn{2}{|c|}{$\%$ of area } \\
\hline & Buyers & sellers & Buyers & Sellers & Buyers & Sellers & Buyers & Sellers \\
\hline Re-use system & 74.7 & 36.5 & 74.8 & 45.4 & 72.2 & 49.2 & 59.4 & $38.5^{2}$ \\
\hline Las er grading & 80.3 & 54.4 & 66.0 & 64.1 & 80.0 & 83.1 & 63.1 & 61.4 \\
\hline Surface drains & 76.9 & 70.2 & 93.1 & 82.6 & 77.8 & 69.8 & 69.7 & 60.5 \\
\hline Off-farm drains & 55.4 & 28.6 & & & 48.8 & 58.5 & 42.0 & 52.6 \\
\hline \multicolumn{2}{|c|}{ Other irrigation system } & & & & 20.0 & 12.3 & 10.9 & 5.7 \\
\hline \multicolumn{9}{|c|}{ Installed it since purchasing the water: } \\
\hline \multicolumn{2}{|l|}{ Re-use system } & 7.9 & & & & & & \\
\hline \multicolumn{2}{|l|}{ laser grading } & 10.4 & & & & & & \\
\hline \multicolumn{2}{|c|}{ On-farm surface drains } & 12.5 & & & & & & \\
\hline \multicolumn{9}{|c|}{ Of the buyers who did not have a re-use system $29 \%$ inteded to get one } \\
\hline & & & & & & & \multicolumn{2}{|c|}{$\%$ of respondents } \\
\hline \multicolumn{6}{|c|}{ Do you have a whole of farm plan } & & 78.4 & $60.3^{2}$ \\
\hline \multicolumn{6}{|c|}{ Do you use aid in scheduling irrigation } & & 18.9 & $9.0^{3}$ \\
\hline \multicolumn{7}{|c|}{ Within the last five years have you improved your irrg. and drainage } & 73.9 & $53.2^{1}$ \\
\hline \multicolumn{7}{|c|}{ Within the last five years have you bought more water right } & 94.0 & $12.9^{1}$ \\
\hline \multicolumn{7}{|c|}{ Within the last five years have you bought more land } & 25.0 & $9.8^{2}$ \\
\hline \multicolumn{7}{|c|}{ Within the last five years have you changed your irrig. production } & 42.6 & 38.4 \\
\hline \multicolumn{7}{|c|}{ Within the last five yaers have you reduced your irrigated area } & 10.2 & $41.0^{1}$ \\
\hline \multicolumn{7}{|c|}{ Within the last five years have you sold water right } & 6.9 & $72.6^{1}$ \\
\hline \multicolumn{7}{|c|}{ In the next five years will you improve your irrigation and drainage } & 54.5 & $42.9^{2}$ \\
\hline \multicolumn{7}{|c|}{ In the next five years will you buy additional water right } & 28.4 & $10.9^{1}$ \\
\hline \multicolumn{7}{|c|}{ In the next five years will you buy additional land } & 24.7 & $10.9^{1}$ \\
\hline \multicolumn{7}{|c|}{ In the next five years will you change your irrigated production } & 31.0 & 25.0 \\
\hline \multicolumn{7}{|c|}{ In the next five years will you reduce your irrigated area } & 2.3 & $14.5^{1}$ \\
\hline \multicolumn{7}{|c|}{ In the next five years will you sell water right } & 1.1 & $15.9^{1}$ \\
\hline
\end{tabular}

\subsection{Entitlement trading and higher valued and more productive water use?}

Traditionally water markets within the GMID have been dominated by the dairy industry as the high-value water user in the region. This is evident during all three periods (table 2). However the dominance of dairy has reduced over time with fewer buyers and more sellers being dairy farmers. This reflects, as previously discussed, the hard economic times that the dairy industry has 
experienced during this period. Still there are a significantly larger percentage of sellers being cattle and sheep farmers. On the buying side there have been and increase in purchases by horticultural producers, but also by cropping and sheep producers and by buyers with no crop which represent new irrigation enterprises as well as golf courses, caravan parks etc. Among the sellers there have been increases in sale by cropping farmers and farmers without irrigation.

Table 2: $\quad$ Land use and farm and entitlement size of buyers and sellers.

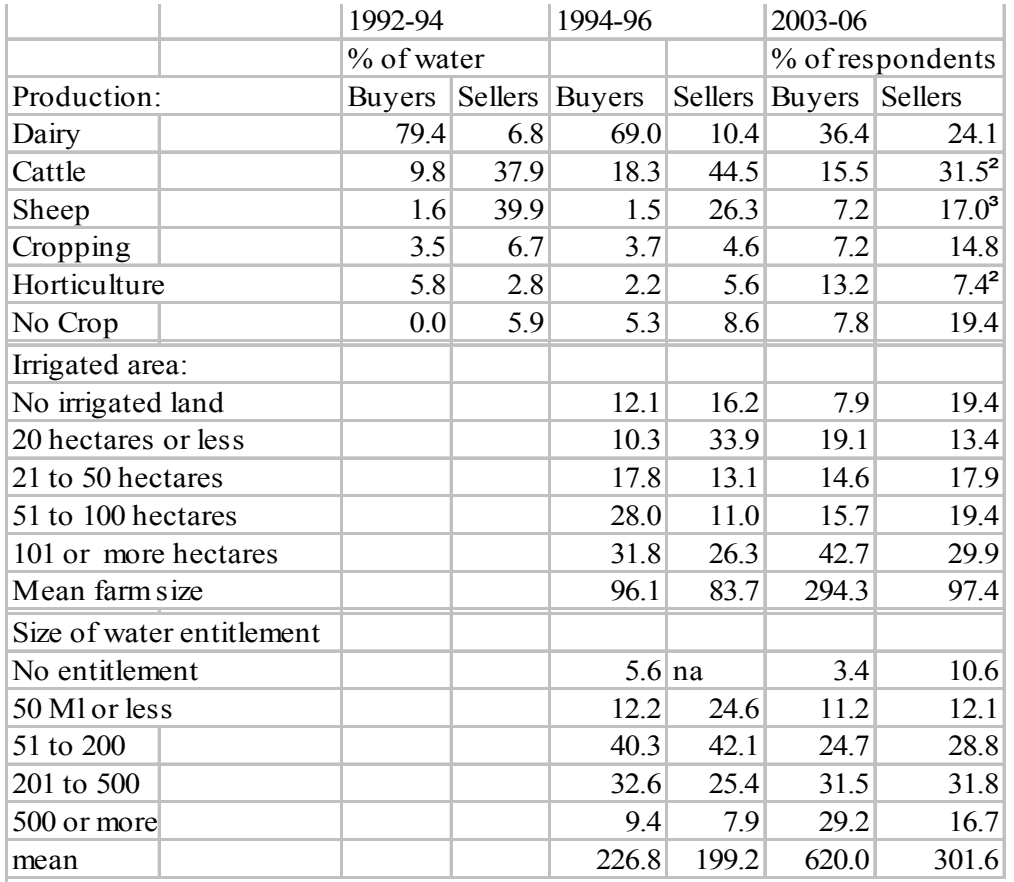

Significance level using Pearson Chi-Square ${ }^{1} 0.01 ;{ }^{2} 0.05 ;{ }^{3} 0.1$

While sellers without irrigation during the early years represented entitlement holders which never had used their water and now used the introduction of trade to sell this unused asset, during the last period many of these sellers represent irrigators who have stopped irrigation recently in response to high water market prices both in the allocation and entitlement market (table 1 shows that $41 \%$ of sellers have reduced their irrigated area the last five years). Surveys of sellers in the seasonal allocation market indicates that as many as $29 \%$ of the sellers do not irrigate at all and instead sell their water each year [13]. Some of these entitlement owners are likely to be tempted to sell their entitlements as the price of these has gone up by some $12.7 \%$ per annum over the last 13 years [14].

The facts that the buyers have more viable and productive farms operated by younger and better agriculturally qualified people, more actively involved in improving their production, also suggest that the buying properties are more productive (table 3 ). The fact that the sellers have a larger proportion with non- 
agricultural qualifications reflects that many of the selling farms are considered to be hobby farms or rural residences. Further, considering that about $7 \%$ of all sellers no longer reside at the address of the property suggests that many are adjusting out of farming. There is evidence that this is part of a longer trend even though previous research [15] suggests that the market for seasonal water allocations seems to delay this process as a large proportion of farmers are using this market to remain on the farm and in the community for the rest of their working life. While buyers and sellers have much the same family background in farming, it is evident that many of the sellers are not commercial farmers but simply live in a rural area while working off-farm. This trend is going to continue since only $24 \%$ of buyers and $14 \%$ of sellers are certain of family continuity of their farm business while a quarter are uncertain, leaving only a quarter to half of the farm businesses in operation after this generation.

Table 3: Demographic information.

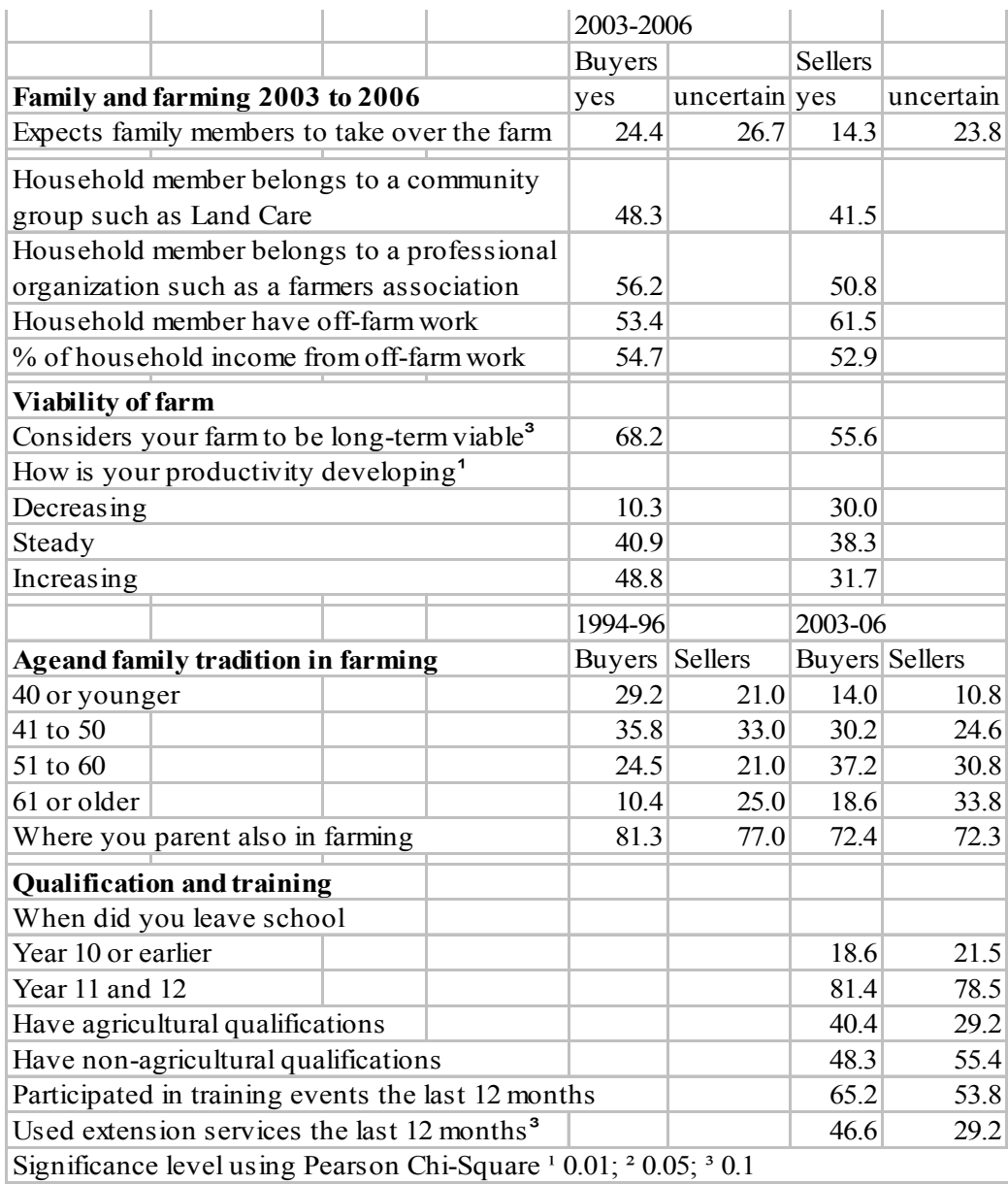




\section{Conclusions}

There is evidence that the entitlement market has an increasing impact on how water is used and that it moves water from less efficient and lower value producing to more efficient and higher value producing farms. While the early water market mainly activated unused water, there is evidence that as the market matures and activates this unused water, more actively used water is being sold reducing the productive capacity of the selling properties. Entitlement markets therefore seem to have an increasing impact on local farming communities. The operation and continued high level of use of the allocation market have slowed this process down, as the current generation of irrigators struggle to stay on their properties and within their communities. This has a beneficial impact on communities' and individuals' ability to adjust and deal with the rapid pace of change. Finally there is strong evidence that the entitlement market in the medium future will have an increasing impact on water allocation and structural change in many communities as only between a quarter and half of the existing farm businesses will remain in operation after this generation.

\section{Acknowledgements}

This research is funded by the Australian Research Council and six industry partners: Murray-Darling Basin Commission, Department of Natural Resources; Department of Sustainability and Environment, Goulburn-Murray Water, Department of Water, Land and Biodiversity Conservation and UpMarket Software Services.

\section{References}

[1] Bjornlund, H. Water Trade Policies as a Component of Environmentally, Socially and Economically Sustainable Water Use in Rural Southeastern Australia. Thesis submitted in fulfilment of the requirement for the degree of doctor of philosophy, University of South Australia, Adelaide, 1999

[2] Bjornlund, H. Formal and informal water markets - Drivers of sustainable rural communities? Water Resources Research 40, W09S07, 2004.

[3] Bjornlund, H. Can water markets assist irrigators managing increased supply risk? Some Australian Experiences. Water International, 31(2), 221-232, 2006.

[4] Bjornlund $\mathrm{H}$ and McKay, J., Aspects of Water Markets for Developing Countries - Experiences from Australia, Chile and the US. Journal of Environment and Development Economics 7(4), 767-793, 2002.

[5] Bjornlund, H. and McKay, J., Are Water Markets Achieving a More Sustainable Water Use. Proceedings from the X World Water Congress, Melbourne, March, 2000.

[6] Bjornlund, H., Increased participation in Australian Water Markets. In Lorenzini, G. and Brebbia, C.A. eds. Sustainable Irrigation Management, Technologies and Policies. Southampton: WIT Press, 289-302, 2006. 
[7] Bjornlund, H., Tradable permits - instruments to manage water scarcity? Some Australian experiences. Proceedings from the International Workshop on Tradeable Permits, Wittenberg, Germany, November , 2006

[8] CoAG, Council of Australian Governments, Communiqué, Meeting of CoAG in Hobart 25 February 1994. 1994

[9] CoAG, Council of Australian Governments, Intergovernmental Agreement on a National Water Initiative. www.dpmc.gov.au, 2004

[10] Bjornlund, H. Water markets and the environment - what the irrigation community told us. Proceedings from the Riversymposium. www.riversymposium.com/index.php?page=GeneralArchive , 2004.

[11] DSE, Department of Sustainability and Environment, Victorian Government White Paper: Securing our water future together. Department of Sustainability and Environment, Melbourne, 2004.

[12] Bjornlund, H., Farmer Participation in markets for temporary and permanent water in southeastern Australia. Agricultural Water Management 63(1), 57-76, 2003.

[13] Bjornlund, H., The Monitoring of, and reporting on, water trading within the Goulburn-Murray Irrigation District, Industry Partner Report of ARC Linkage Grant Water Scarcity and Rural Social Hardship - can water markets alleviate the problems? University of South Australia. For copy henning.bjornlund@unisa.edu.au.2006

[14] Bjornlund, H. and Rossini, P., tracing evidence of rational investor behaviour in water markets - revisited. Proceedings from the $13^{\text {th }}$ Annual Conference of the Pacific Rim Real Estate Society, Fremantle, Western Australia, January. www.business.unisa.edu.au/prres. 2007

[15] Bjornlund, H. The socio-economic structure of irrigation communities water markets and the structural adjustment process. Journal of Rural Society 12(2), 123-145, 